\title{
Diets and bathymetric distributions of two bathyal sharks of the Catalan deep sea (western Mediterranean)
}

\author{
M. Carrassón ${ }^{1}$, C. Stefanescu ${ }^{2}$, J. E. Cartes ${ }^{2}$ \\ ${ }^{1}$ Unidad de Zoología, Departamento de Biología Animal, Universidad Autónoma de Barcelona, Bellaterra, E-08193 Barcelona, \\ Spain \\ ${ }^{2}$ Instituto de Ciencias del Mar-CSIC, Paseo Nacional s/n, E-08039 Barcelona, Spain
}

\begin{abstract}
ABSTRAC'T: Bathymetric distribution of Centroscymnus coelolepis has been studied. This species was restricted to the lower slope $(1419$ to $2251 \mathrm{~m})$, where it was the only abundant shark. Caleus melastomus was abundant below $1000 \mathrm{~m}$ but became rare between 1400 and $1600 \mathrm{~m}$, so that there is almost no bathymetric overlap with $C$. coelolepis. Greatest abundance of $G$. melastomus in the Catalan Sea was found in the upper slope. Diets of both species showed a very low overlap which is mainly attributed to the dietary specialization of C. coelolepis. Its diet is almost exclusively based on cephalopods. The diet of $G$. melastomus has been analyzed at depths below $1000 \mathrm{~m}$. Its diet is more diverse than that of $C$. coelolepis and cephalopods are not preferential prey. The upper and middle slope specimens of $G$. melastomus have a different diet; this difference may be the consequence of a change in avalable resources. Finally the trophic position of Etmopterus spinax, the third most abundant shark below $1000 \mathrm{~m}$, seems to be more similar to that of $\mathrm{C}$. coelolepis. These results suggest that a possible competition is more likely between $C$. coelolepis and E. spinax than between $C$. coelolepis and $G$. melastomus. This could explain the bathymetric displacement of $C$. coelolepis in the western Mediterranean as a result of an interaction between species of higher trophic levels.
\end{abstract}

\section{INTRODUCTION}

Information on the distribution and biology of bathyal sharks in the deep Mediterranean Sea (below a depth of $1000 \mathrm{~m}$ ) is limited and fragmentary.

The bathymetric distribution of Centroscymnus coelolepis Bocage \& Capello, 1864, the only abundant species at great depths in the Mediterranean Sea, has been partially determined. Subsequent to the synthesis made by Grey (1956), the published data were incomplete (Tortonese 1956, Torchio \& Michelangeli 1971, Allué et al. 1985, Della Croce et al. 1988). The trophic habits of this species have been studied in some areas of the Atlantic and Pacific Oceans (Clarke \& Merrett 1972, Marshall \& Merrett 1977, Sedberry \& Musick 1978, Mauchline \& Gordon 1983, Yano \& Tanaka 1988), but they are completely unknown in the Mediterranean.

There is plentiful information about Galeus melastomus Rafinesque, 1810, although it is usually limited to commercial grounds, between 200 and $700 \mathrm{~m}$
(Capapé \& Zaouali 1976, 1977, Relini Orsi \& Wurtz 1977. MacPherson 1980, Mattson 1981, Mauchline \& Gordon 1983, among others). Recently, Golani (1986/87) found this species below $1000 \mathrm{~m}$, off the coast of Israel, and reported preliminary data on its diet at these depths.

Diet analysis allows the study of the trophic overlap among species within a community. This parameter is essential in determining the intensity of the interspecific interactions (i.e. in marine fish communities: MacPherson 1979, 1981, Blaber \& Bulman 1987, among others). For deep-sea sharks, the available data on trophic overlap are scarce. Mauchline \& Gordon (1983) discussed some preliminary data at Rockall Trough (NW Ireland); this aspect was also studied by MacPherson (1980) in the upper slope of the Catalan Sea.

Bathymetric distribution, trophic habits and trophic interactions of Centroscymnus coelolepis and Galeus melastomus are presented in this work. These aspects are analyzed within groups of immature and adult 
sizes. The diet of $G$. melastomus is described and compared in 2 bathymetric levels which correspond to the upper and middle slope respectively. Finally, we discuss the possible competitive interactions and the habitat segregation among the most common sharks which inhabit the slope below $1000 \mathrm{~m}$.

\section{MATERIALS AND METHODS}

All material was collected from the continental slope of the Catalan Sea (western Mediterranean, $38^{\circ} 45^{\prime}$ to $42^{\circ} 00^{\prime} \mathrm{N}, 01^{\circ} 30^{\prime}$ to $02^{\circ} 50^{\prime} \mathrm{E}$ ), during cruises carried out within the framework of the BATIMAR, ABISMAR and PONT'90 projects (1988 to 1990). The specimens were captured with a semi-balloon otter trawl (OTSB14) (cf. Merrett \& Marshall 1981) and with longlines. Specimens of Galeus melastomus from the upper slope were also obtained from commercial trawls.

To define the bathymetric distribution below a depth of $1000 \mathrm{~m}$, we used records of 76 specimens of Galeus melastomus and 62 of Centroscymnus coelolepis, captured exclusively by the OTSB14. We divided the slope sampled (984 to $2251 \mathrm{~m}$ ) into 6 equivalent bathymetric zones of $200 \mathrm{~m}$ each, and calculated the abundance of the species in each zone. Prior to the calculations, data were standardized to number per hour of trawling. In each zone, the number of individuals per hour was determined as the arithmetic mean of the total number of samples taken within these intervals.

A total of 86 specimens of Centroscymnus coelolepis and 99 of Galeus melastomus were examined to determine their diet. Moreover, to compare their trophic habits, a few specimens of Etmopterus spinax L., 1759 collected with the OTSB14 below $1000 \mathrm{~m}$ were analyzed. These data were not included in the results because of the small number of individuals studied Immediately after capture, specimens were fixed in $10 \%$ formalin. Once in the laboratory, they were measured and dissected for analyis of stomach content.

The food items were identified to the lowest taxonomic level possible. We registered their number and weight to the nearest $0.1 \mathrm{mg}$, after drying them with blotting-paper to remove surface moisture. In the case of the Foraminifera, we always assigned an abundance of 1 because they were passively ingested (Lagardère 1977).

The quantitative importance of every prey group in the diets of both species was determined by the Index of Relative Importance (Pinkas et al. 1971), which was defined as

$$
\operatorname{IRI}=F(N+V)
$$

where $F=$ frequency of occurrence of the food item; $N=$ numerical percentage of a food item in the stomachs, and $V=$ percentage by volume of the food item in the stomachs (Hureau 1970). In our study we used weight $(W)$ instead of volume $(V)$. This index has been expressed as \%IRI $=\left(I R I / \sum I R I\right) \times 100$. Prey were sorted in decreasing order according to their \%IRI contribution, and then cumulative \%IRI was calculated. Prey were classified into the 3 following categories according to their contribution to the cumulative \% IRI (Rossechi \& Nouaze 1987): preferential prey (those whose cumulative \%IRI attains at least $50 \%$ of the total \%IRI); secondary prey (those whose cumulative $\%$ IRI, when added to that of preferential prey, attains at least $75 \%$ of the total \%IRI); and accidental prey (the remaining prey)

Diet was studied according to the different sizeclasses in both species. We considered 2 size-groups which generally corresponded with the immature specimens (total length $<40 \mathrm{~cm}$ ) and mature specimens (total length $\geq 40 \mathrm{~cm}$ ). The maturity size of Galeus melastomus was previously determined in the study area by MacPherson (1980). Maturity length of Centroscymnus coelolepis was determined from personal observations

The diet of Galeus melastomus was determined for 2 different bathymetric strata 371 to $667 \mathrm{~m}$ and 984 to $1584 \mathrm{~m}$ ), which approximately correspond to the upper and middle slope. All of Centroscymnus coelolepis specimens were captured in the lower slope (1729 to $2251 \mathrm{~m}$ ).

We determined the cumulative trophic diversity curves in the same way as Mauchline \& Gordon (1985). The Shannon-Wiener index (Shannon \& Weaver 1949) was calculated on the abundance values of prey for each specimen. The asymptotic stabilization of the curves indicates the minimum number of stomachs that have to be analyzed in order to get reliable enough results.

Degree of overlap in the diet of both species, by different sizes and bathymetric levels, was determined using the quantitative Schoener index (Schoener 1974) and the semi-quantitative Spearman correlation coefficient (Sokal \& Rohlf 1969). Trophic diversity $\left(H^{\prime}\right)$ was calculated using the \%IRI values and the Shannon-Wiener index.

\section{RESULTS}

\section{Bathymetric distributions}

Centroscymnus coelolepis

The bathymetric preferences of Centroscymnus coelolepis in the Catalan Sea (which has a maximum depth of about $2400 \mathrm{~m}$ ) are represented in Fig. 1 This 


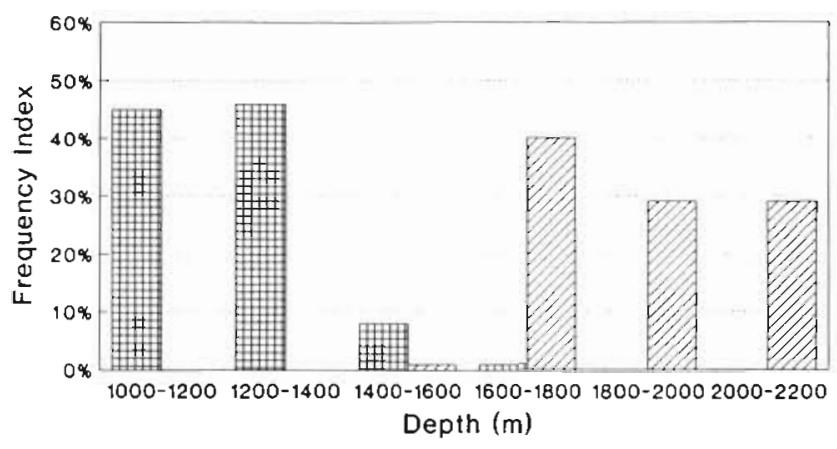

\#相 G. melastomus WA c. coelolepis

Fig. 1 Galeus melastomus, Centroscymnus coelolepis, Bathymetric distribution of 2 bathyal sharks in the Catalan Sea below a depth of $1000 \mathrm{~m}$

species is found almost exclusively on the lower slope, where it is the only common shark; the upper limit is about $1419 \mathrm{~m}$, although it is a very rare species at depths less than $1600 \mathrm{~m}$. The complete absence of this shark in the upper and middle slope is corroborated by the absence of published records in an area where intensive sampling of the demersal fauna has been carried out.

Fig. 2 represents the bathymetric distribution of all specimens by size and sex. There is a possible trend in sexual and ontogenetic segregation by depth although

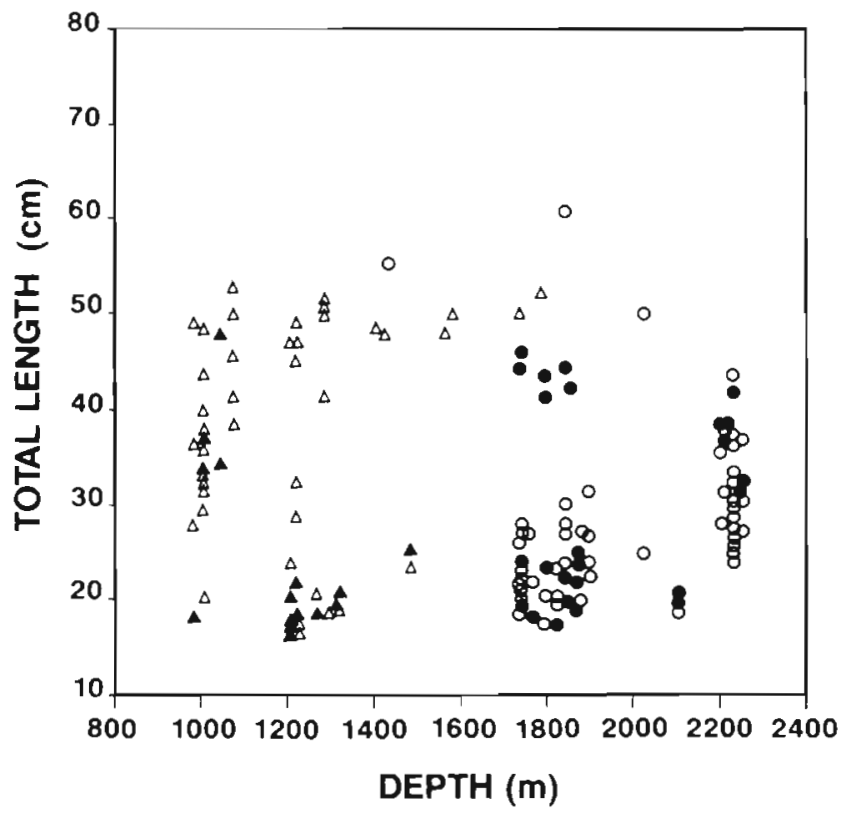

- G. melastomus o

- C. coelolepis $0^{x}$

$\triangle$ G. melastomus

- c. coelolepis ?

Fig. 2. Galeus melastomus, Centroscymnus coelolepis. Bathymetric distribution by sizes and sex of 2 bathyal sharks in the Catalan Sea below a depth of $1000 \mathrm{~m}$ more data would be required to confirm this. Adult males and females (length $\geq 40 \mathrm{~cm}$ ) were found between 1700 and $1900 \mathrm{~m}$, as were immature males and females $(20$ to $30 \mathrm{~cm}$ ). The largest specimens of both sexes were not present at the greatest depths. Below a depth of $2000 \mathrm{~m}$ sharks of intermediate size $(30$ to $40 \mathrm{~cm}$ ) prevailed.

\section{Galeus melastomus}

In the western Mediterranean, Galeus melastomus is the most abundant demersal shark on the upper and middle slope (Relini Orsi \& Wurtz 1977. Allué 1985, Bauchot 1987a).

In our study, we found that Galeus melastomus was abundant from $1000 \mathrm{~m}$ to as deep as $1400 \mathrm{~m}$. Below that depth, numbers declined very sharply and it became rare (Fig. 1).

Bathymetric distribution of Galeus melastomus by size and sex is shown in Fig 2. At the limit of the bathymetric range adult males disappear and only immature males of 10 to $20 \mathrm{~cm}$ total length are found. On the other hand, immature and adult females of about 10 to $61 \mathrm{~cm}$ are present at the greatest depths.

\section{Diet}

\section{Centroscymnus coelolepis}

Table 1 shows the results of stomach content analysis for 86 specimens. The high percentage of empty stomachs $(41.2 \%)$ is an obstacle to conclusions in the case of mature individuals (Fig. 3). In general the diet consisted almost exclusively of cephalopods, decapods and fishes. This low diversity can be seen in Table 2c.

The relative importance of the different prey groups is shown in Fig. 4. It emphasizes the dominant role of the cephalopods, in which the combination of frequency and great abundance together with their high weight results in a \%IRI of 87.2. Decapods and fishes can be considered as casual prey groups. The contribution of the remaining prey was minimal $1 \%$ IRI $\leq 0.3)$

Important ontogenic changes in the diet are evident in Table 1 . The low value of overlap between both sizegroups (27.6) corroborates this (Table 2b).

In both size-groups, cephalopods were always the preferred prey. Natantia decapods made an important contribution to the diet of the immatures. There was an obvious preference for the caridean Acanthephyra eximia (\%IRI $=12.4)$, which is by far the most abundant decapod in the Mediterranean deep sea (Cartes 1991). There was a total absence of decapods in the adult diet. 
Table 1 Centroscymnus coelolepis. Qualitative and quantitative composition of diet by size-classes. F: frequency; $N$ : percentage by number; $W$ : percentage by weight

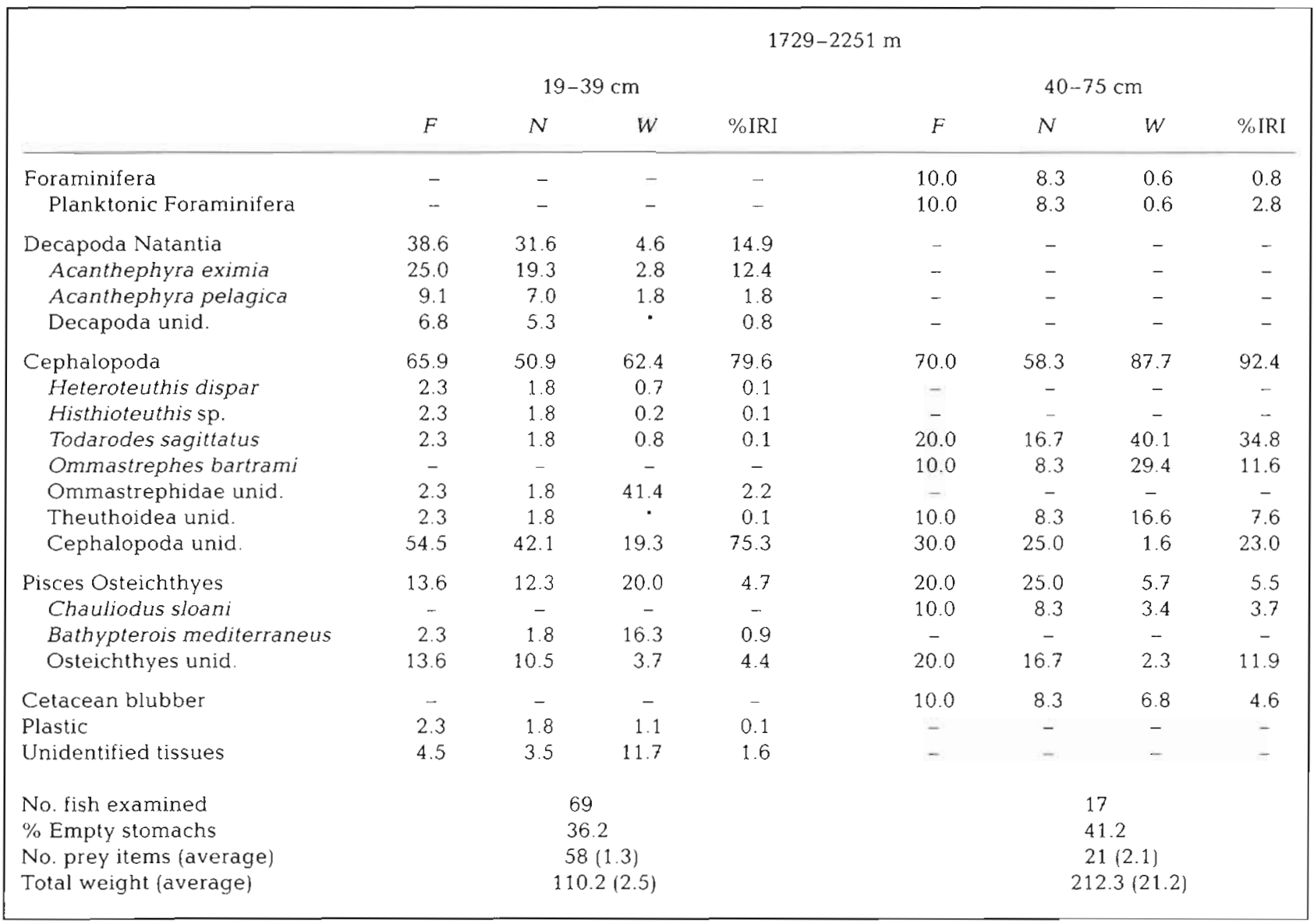

\section{Galeus melastomus}

Table 3 shows the results of the stomach analysis of 99 individuals. The percentage of empty stomachs was very low $(10.2 \%$ in the middle slope and null in the upper slope). In all size-groups we studied, diets were determined with sufficient accuracy (Fig. 3). Three prey groups (Natantia decapods, fishes and cephalopods) mainly dominated the diet on the middle slope (Fig. 4C). On the upper slope, euphausiids and Macrura decapods were also seen. Differences were also noted between the size-classes in each bathymetric zone.

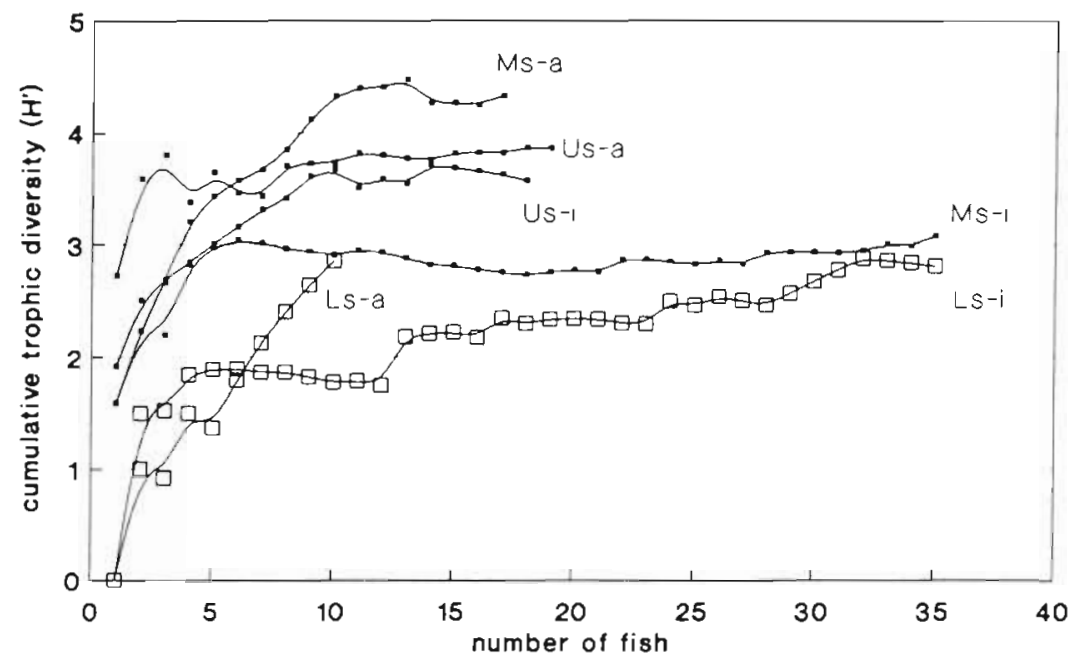

Fig. 3. Galeus melastomus, Centroscymnus coelolepis. Cumulative trophic diversity curves for different size and bathymetric groups for (*) G. melastomus and (ㅁ) $C$. coelolepis. Us: upper slope; Ms: middle slope; Ls: lower slope; a: adults; i: immatures 
Table 2. Centroscymnus coelolepis, Galeus melastomus (a) Spearman correlation coefficient between the different groups established ("significant at $p \leq 0.05)$. (b) Overlap Schoener index. (c) Trophic diversity $\left(\mathrm{H}^{\prime}\right)$. All calculations were made using \%IRI. CCI: Immatures of $C$ coelolepis; CCA: adults of C. coelolepis; GMIU: immatures of G. melastomus (upper slope); GMAU: adults of $G$. melastomus (upper slope); GMIM: immatures of G. melastomus (middle slope); GMAM: adults of $G$. melastomus (middle slope)

\begin{tabular}{|c|c|c|c|c|c|}
\hline \multicolumn{6}{|c|}{ a. Spearman correlation } \\
\hline & $\mathrm{CCA}$ & GMIU & GMAU & GMIM & GMAM \\
\hline $\mathrm{CCl}$ & 0.08 & $-0.56^{\bullet}$ & -0.35 & -0.05 & 0.30 \\
\hline $\mathrm{CCA}$ & - & $-0.46^{\circ}$ & -0.30 & -0.16 & 0.02 \\
\hline GMIU & - & - & 0.47 & 0.03 & -0.12 \\
\hline GMAU & - & - & - & 0.05 & -0.10 \\
\hline GMIM & - & - & - & - & 0.14 \\
\hline \multicolumn{6}{|c|}{ b. Overlap Schoener index } \\
\hline & $\mathrm{CCA}$ & GMIU & GMAU & GMIM & GMAM \\
\hline $\mathrm{CCI}$ & 27.6 & 5.7 & 5.8 & 28.6 & 23.6 \\
\hline $\mathrm{CCA}$ & - & 9.5 & 21.6 & 34.8 & 31.3 \\
\hline GMIU & - & - & 23.6 & 20.5 & 16.1 \\
\hline GMAU & - & - & - & 58.9 & 43.4 \\
\hline GMIM & - & - & - & - & 51.4 \\
\hline \multicolumn{6}{|c|}{ c. Trophic diversity } \\
\hline \multicolumn{6}{|c|}{$\mathrm{H}^{\prime}$} \\
\hline $\mathrm{CCI}$ & \multicolumn{2}{|c|}{1.34} & & & \\
\hline $\mathrm{CCA}$ & \multicolumn{2}{|c|}{2.48} & & & \\
\hline GMIU & \multicolumn{2}{|c|}{1.78} & & & \\
\hline GMAU & \multicolumn{2}{|c|}{2.57} & & & \\
\hline GMIM & \multicolumn{2}{|c|}{2.48} & & & \\
\hline GMAM & \multicolumn{2}{|c|}{3.47} & & & \\
\hline
\end{tabular}

Upper slope. We identified 45 prey from a total of 60 stomachs. Natantia decapods and euphausiids were the preferred prey, fishes and Macrura decapods were secondary and cephalopods and the rest were accidental (Fig. 4B). At the species level Calocaris macandreae and Pasiphaea multidentata were the most exploited prey; both species are predominant elements of the benthic and benthopelagic fauna in the upper slope of the Catalan Sea (Abello et al. 1988).

There were important differences between the diets of immature and adult specimens. These differences are shown by low values in the overlap (Table 2b). Calocaris macandreae, which is the preferential prey of the immatures ( $\% \mathrm{IRI}=62.8)$, is only a casual prey in the adults ( $\%$ IRI $=4.1)$. The importance of euphausiids is also considerably reduced. On the other hand fishes and Pasiphaea multidentata are more common in the adults. The cephalopods, which hardly appear in the diet of the immatures, are a secondary prey in the adults.

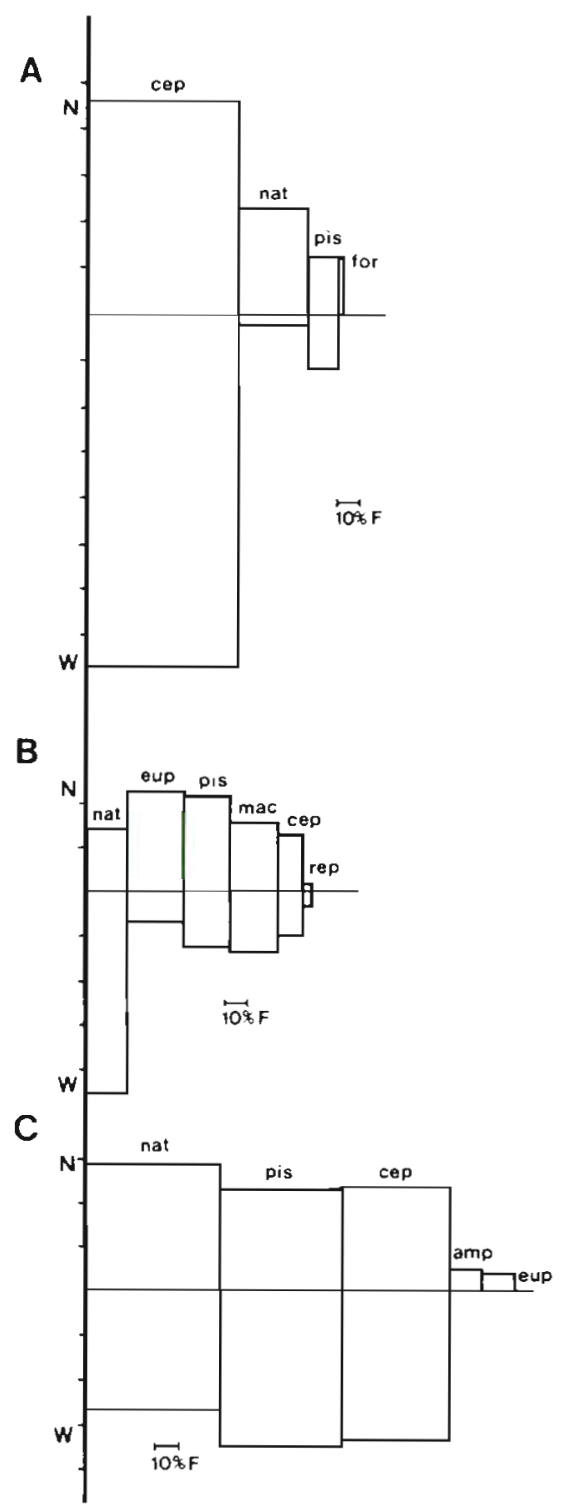

Fig. 4. Relative importance of prey groups to (A) Centroscymnus coelolepis, (B) Galeus melastomus (upper slope), and (C) Galeus melastomus (middle slope). Areas of rectangles are proportionate to the IRI. F: Frequency in \% of a prey group (width of rectangle); $N$ : percentage by number of a prey group; W: percentage by weight of a prey group; cep: Cephalopoda; nat: Decapoda Natantia; pis: Pisces; for: Foraminifera; amp: Amphipoda; eup: Euphausiacea; mac: Decapoda Macrura; rep: Decapoda Reptantia

Middle slope. 43 prey items were identified from a total of 39 stomachs examined. In the large size-class, diversity was low because Natantia decapods, fishes and cephalopods were preferred prey (\%IRI $=97.7)$. Pasiphaea multidentata was the most abundant prey species; its weight was less than other prey items such as Todarodes sagittatus or Mora moro, but it was much more frequently captured. 
Table 3. Galeus melastomus. Qualitative and quantitative composition of diet by bathymetric and size-groups. F: frequency; $N$ : percentage by number; $W$ : percentage by weight. "Values $<0.1 \%$

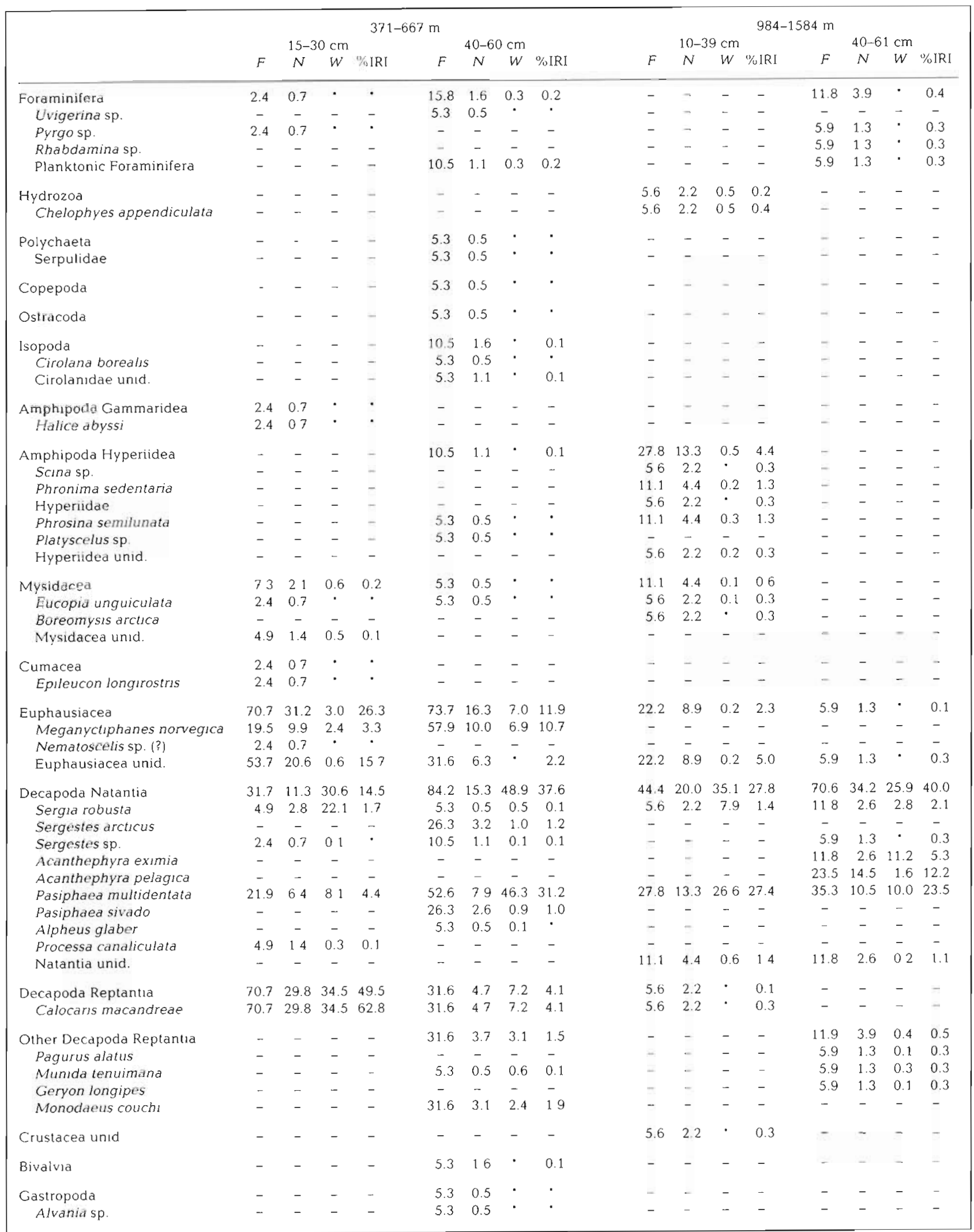


Table 3 (continued)

\begin{tabular}{|c|c|c|c|c|c|c|c|c|c|c|c|c|c|c|c|c|}
\hline & \multicolumn{8}{|c|}{$371-667 \mathrm{~m}$} & \multicolumn{8}{|c|}{$984-1584 \mathrm{~m}$} \\
\hline & \multicolumn{4}{|c|}{$15-30 \mathrm{~cm}$} & \multicolumn{4}{|c|}{$40-60 \mathrm{~cm}$} & \multicolumn{4}{|c|}{$10-39 \mathrm{~cm}$} & \multicolumn{4}{|c|}{$40-61 \mathrm{~cm}$} \\
\hline & F & $N$ & W & $\% \mathrm{IRI}$ & F & $N$ & $w$ & $1 \%$ IRI & $F$ & $N$ & $w$ & $\%[R I$ & $F$ & $N$ & $w$ & $\%[R]$ \\
\hline Cephalopoda & 7.3 & 21 & 0.4 & 0.2 & 73.7 & 21.1 & 170 & 19.5 & 38.9 & 22.2 & 5.2 & 12.2 & 52.9 & 25.0 & 36.6 & 30.6 \\
\hline Heteroteuthis dispar & - & - & - & - & 5.3 & 0.5 & 5.6 & 0.4 & - & - & - & - & - & - & - & - \\
\hline Chiroteuthis verany! & - & - & - & _- & - & - & - & - & 5.6 & 22 & - & 0.3 & 5.9 & 1.3 & 06 & 0.4 \\
\hline Galiteuthis armata & - & - & - & - & - & - & - & - & - & - & - & - & 5.9 & 2.6 & 1.0 & 0.7 \\
\hline Histhioteuthis sp. & - & - & - & - & - & - & - & - & - & - & - & - & 5.9 & 26 & 10 & 0.7 \\
\hline Todarodes sagittatus & - & - & - & - & 10.5 & 1.1 & 7.5 & 1.0 & - & - & - & - & 5.9 & 1.3 & 29.5 & 5.9 \\
\hline Ommastrephidae unid. & - & - & - & - & - & - & - & - & - & - & - & - & 11.8 & 3.9 & 1.4 & 2.0 \\
\hline Teuthoidea unid. & 2.4 & 0.7 & 0.1 & - & 47.4 & 15.8 & 3.6 & 10.0 & - & - & - & - & 11.8 & 3.9 & 0.5 & 1.7 \\
\hline Bathypolypus sponsalis & - & - & - & - & - & - & - & - & - & - & - & - & 5.9 & 1.3 & 0.4 & 0.3 \\
\hline Cephalopoda unıd. & 4.9 & 1.4 & 0.3 & 0.1 & 21.1 & 3.7 & 0.4 & 1.0 & 38.9 & 20.0 & 5.2 & 24.2 & 29.4 & 7.9 & 1.9 & 9.3 \\
\hline Brachiopoda & - & _- & - & - & - & - & - & - & - & - & - & - & 5.9 & 1.3 & 0.8 & 0.1 \\
\hline Gryphus sp. & - & - & - & - & - & - & - & - & - & - & - & - & 5.9 & 1.3 & 0.8 & 0.4 \\
\hline Tunicata & - & -- & - & - & 15.8 & 1.6 & 1.7 & 0.4 & - & - & - & - & 5.9 & 1.3 & 0.2 & 0.1 \\
\hline Pyrosomida & - & -. & - & - & - & - & - & - & - & - & - & -- & 5.9 & 1.3 & 0.2 & 0.3 \\
\hline Salpıdae & - & - & - & - & 15.8 & 1.6 & 1.7 & 0.6 & - & - & - & - & - & - & - & - \\
\hline Pisces Osteichthyes & 415 & 13.5 & 2.8 & 7.4 & 89.5 & 27.4 & 13.2 & 25.2 & 55.6 & 24.4 & 58.3 & 52.3 & 52.9 & 22.4 & 32.7 & 27.5 \\
\hline Chauliodus sloani & - & - & - & - & - & - & - & - & - & - & - & - & 11.8 & 2.6 & 3.2 & 2.2 \\
\hline Stomias boa boa & - & -- & - & - & 5.3 & 0.5 & 0.6 & 01 & - & - & - & - & - & - & - & - \\
\hline Symbolophorus veranyı & - & - & - & - & 5.3 & 0.5 & 3.1 & 0.2 & - & - & - & - & - & - & - & - \\
\hline Notolepis rissor & - & - & - & - & 5.3 & 0.5 & 0.3 & • & - & - & - & - & - & - & - & - \\
\hline Mesopelagic fishes & - & - & - & - & - & - & - & - & - & - & - & - & 5.9 & 1.3 & 3.0 & 0.8 \\
\hline Coelorhynchus coelorhynchus & - & - & - & - & 5.3 & 0.5 & 0.3 & . & - & - & - & - & - & - & - & - \\
\hline Antonogadus megalokynodon & - & - & - & - & - & - & - & - & 5.5 & 4.4 & 55.6 & 8.2 & - & - & - & - \\
\hline Mora moro & - & - & - & - & - & - & - & - & - & - & - & - & 11.8 & 2.6 & 26.3 & 11.0 \\
\hline Osteichthyes unid. & 415 & 13.5 & 2.8 & 9.3 & 89.5 & 25.3 & 8.8 & 33.3 & 50.0 & 20.0 & 2.7 & 28.0 & 29.4 & 15.8 & 0.3 & 15.3 \\
\hline Scales & 4.9 & 1.4 & - & 0.1 & - & - & - & - & - & - & - & - & - & - & - & - \\
\hline Chicken leg & 24 & 0.7 & 26.5 & 0.9 & - & - & - & - & - & - & - & - & - & - & - & - \\
\hline Coal & - & - & - & - & _- & - & - & - & - & - & - & - & 11.8 & 2.6 & 1.2 & 1.5 \\
\hline Plant debris & 4.9 & 1.4 & . & 0.1 & - & - & - & - & - & - & - & - & - & - & - & - \\
\hline Remains of carton & - & - & - & - & - & - & - & - & - & - & - & - & 5.9 & 1.3 & 1.4 & 0.5 \\
\hline Plastic & - & - & - & - & 5.3 & 0.5 & 1.5 & 0.1 & - & - & - & - & 5.9 & 1.3 & 1.1 & 0.5 \\
\hline Synthetic fibres & - & - & - & - & 5.3 & 0.5 & - & - & - & - & - & - & - & - & - & - \\
\hline Unidentifıed tıssues & 14.6 & 4.2 & 1.5 & 1.2 & - & - & - & - & - & - & - & - & 5.9 & 1.3 & $\cdot$ & 0.3 \\
\hline No. fish examined & \multicolumn{4}{|c|}{41} & \multicolumn{4}{|c|}{19} & & \multicolumn{4}{|c|}{18} \\
\hline$\%$ Empty stomachs & \multicolumn{4}{|c|}{0.0} & \multicolumn{4}{|c|}{0.0} & \multicolumn{4}{|c|}{14.3} & \multicolumn{4}{|c|}{5.6} \\
\hline No. prey items (average) & \multicolumn{4}{|c|}{$141(3.4)$} & \multicolumn{4}{|c|}{$190\{10.0\}$} & \multicolumn{4}{|c|}{$45(2.5)$} & \multicolumn{4}{|c|}{$76(4.5)$} \\
\hline Total weight (average) & \multicolumn{4}{|c|}{$18.1(0.4)$} & \multicolumn{4}{|c|}{$72.4(3.8)$} & & 11.7 & $(0.7)$ & & & 112.3 & $3(6.6)$ & \\
\hline
\end{tabular}

Immature fish had a high diversity diet; there were some prey types such as hyperiid amphipods and mysids, which did not appear in the diet of the adults. In this group we could distinguish between the preferred prey (fishes, \%IRI $=52.3$ ), secondary prey (Natantia decapods, \%IRI $=27.8$ ) and the accidental prey (cephalopods, amphipods and euphausiids). In the diet of adults we can only distinguish between the preferred prey (Natantia decapods, cephalopods and fishes, with a $\sum \%$ IRI $=98.1$ ) and the accidental prey. In both groups, Pasiphaea multidentata was the dominant prey item, but the relative importance of other prey changed from one case to the other. The overlap between both size groups showed an intermediate value and there is no correlation in the order of importance of prey items (Table 2a, b).

\section{DISCUSSION AND CONCLUSIONS}

In this work, the distribution of Centroscymnus coelolepis has been accurately determined. This species was exclusive to the lower slope (1500 to $2250 \mathrm{~m}$, sensu Haedrich \& Merrett 1988), where it was the only abundant shark. In the rest of the western Mediterranean Sea it presumably shows the same preferences, although extending to abyssal grounds over $2500 \mathrm{~m}$. Grey (1956) analyzed the data of 42 individuals (1350 to $2718 \mathrm{~m}$ ) and concluded that its center of distribution was below $2000 \mathrm{~m}$.

The records of this species from 200 to $400 \mathrm{~m}$ (cf. Bauchot 1987b, Fredj \& Maurin 1987) are probably incorrect. They may be a consequence of the extrapolation of the bathymetric range shown in the Atlantic Ocean. In Atlantic waters Centroscymnus coelolepis is 
common from the middle slope to the upper rise (Haedrich \& Merrett 1988) and off the Japanese coast it is captured between 100 to $1500 \mathrm{~m}$ (Yano \& Tanaka 1984, 1988). Though in the western Mediterranean there is a substantial amount of information related to the ichthyofauna of the upper slope (e.g. see Allué (1985) and references cited therein), C. coelolepis has never been sited in this bathymetric zone.

This preference for deeper waters in the Mediterranean cannot be explained by hydrographic factors such as temperature or salinity, because they remain constant (about $13^{\circ} \mathrm{C}$ and $38.4 \mathrm{ppm}$, respectively) from $200 \mathrm{~m}$ downwards (Salat \& Cruzado 1981). A possible reason could be a displacement of the spatial niche of Centroscymnus coelolepis to avoid competing against other species with similar trophic habits such as Galeus melastomus.

Galeus melastomus was abundant below $1000 \mathrm{~m}$ but it suddenly became rare between 1400 to $1600 \mathrm{~m}$, so that there is almost no bathymetric overlap with Centroscymnus coelolepis.

As with Centroscymnus coelolepis, there are some differences in the bathymetric distribution of Galeus melastomus in the Mediterranean Sea and in the Atlantic Ocean. According to the literature this species occurs between 55 and 1000 m (Compagno 1984), preferably at the 200 to $500 \mathrm{~m}$ level. In Mediterranean waters, Bauchot (1987a) and Fredj \& Maurin (1987) quote the same range. Later, Golani (1986/87) reported on the exceptional capture of 2 individuals at $1440 \mathrm{~m}$, off the coast of Israel.

The greatest abundance of this species in the Catalan Sea is found in the upper slope (Allue 1985), but we can state that it is frequent to $1400 \mathrm{~m}$. Below that depth it quickly becomes rare. Its lower bathymetric limit is extensive as indicated by the capture of 2 females at 1739 and $1794 \mathrm{~m}$ respectively. In the rest of the western Mediterranean, Galeus melastomus is probably common to $1400 \mathrm{~m}$, and not to $1000 \mathrm{~m}$ as was earlier believed.

The diets of Centroscymnus coelolepis and Galeus melastomus showed a very low overlap which was mainly due to the dietary specialization of C. coelolepis. This species almost exclusively consumes cephalopods, which accounts for the low value of its trophic diversity $\left(H^{\prime}=1.34\right.$ to 2.48$)$. The Mediterranean data suggest that $C$. Coelolepis is not a species of strong scavenger habits, as has been indicated in the Atlantic populations (Clarke \& Merrett 1972, Sedberry \& Musick 1978, Mauchline \& Gordon 1983). In the Catalan Sea it is an active predator on pelagic organisms (cephalopods and, in immatures, decapod crustaceans), which are known to have important migratory habits (Foxton 1972, Roper 1972). The presence of some remains that could be attributable to a scaven- ging activity (e.g. cetacean blubber) was rare in both size-groups. Also, the maximum size which has been recorded in the Mediterranean (about $70 \mathrm{~cm}$ ) is much less than that found in the Atlantic and Pacific Oceans (Compagno 1984). Moreover, because there are some ontogenetic variations in the diet, the results of this work are not comparable with those obtained elsewhere.

For the first time, the diet of Galeus melastomus has been analyzed at depths between 1000 and $1600 \mathrm{~m}$. Its diet was more diverse $\left(H^{\prime}=1.78\right.$ to 3.47$)$ than $C e n-$ troscymnus coelolepis. Cephalopods did not represent a large portion of the diet of $G$. melastomus. It consumed epibenthic and/or benthopelagic species throughout its whole bathymetric range. On the upper slope, the immatures captured mainly Calocaris macandreae and secondarily euphausiids while the adults preferred the benthopelagic species (Ommastrephidae, mesopelagic fishes and Pasiphaea multidentata). This tendency remained in the middle slope for all sizes.

The diets of upper- and middle-slope specimens were different and may be the consequence of a change in available resources. The small contribution of Calocaris macandreae to the diet of the middle slope immature individuals parallels the scarceness of this species below $1000 \mathrm{~m}$ (authors unpubl.). Something similar occurs with the mesopelagic prey: the euphausiid Meganyctiphanes norvegica (the species that reaches the greatest depths in the Mediterranean) is only abundant to $1000 \mathrm{~m}$ (Lagardère 1977). Moreover, it is accepted that $1000 \mathrm{~m}$ is the lower limit of the diel mesopelagic fish migration (Goodyear et al. 1972, Marshall 1979).

The scarcity of the preferred prey and the disappearance of the dominant resources resulted in a diversification in the diet of Galeus melastomus below $1000 \mathrm{~m}$ in all size-classes. In general, the ontogenic differences could be attributed to the fact that most of the adults select large-size prey (cephalopods, Mora moro, Geryon longipes, Pagurus alatus), rather than amphipods, mysids and euphausiids. There was also evidence (pieces of prey too large in relation to the predator's size) which perhaps implies that adult Galeus melastomus hunt in groups, as Springer (1967) already suggested for the small sharks.

As in the case of Centroscymnus coelolepis, Galeus melastomus only occasionally acts as a scavenger species.

Diets of these 2 sharks have been shown to be different as revealed by both the Spearman correlation coefficient and the overlap Schoener index. These values must be carefully interpreted. The level of prey identification (especially cephalopods and fishes) is not the same in all cases. In large measure it depends on the 
advanced level of digestion. Moreover, differences in resource availability in the bathymetric ranges occupied by both species undoubtedly increase such low values of overlap.

If Centroscymnus coelolepis and Galeus melastomus had the same bathymetric distribution, it is possible that their diets would be more similar. It is interesting to note that the adult specimens of $G$. melastomus that inhabit greater depths (exclusively females, see Fig. 2), and whose bathymetric range overlaps with that of C. coelolepis, show a tendency to take cephalopods as their preferred prey (observations of 2 individuals captured between 1500 and $1584 \mathrm{~m}$, Table 3).

The trophic position of Etmopterus spinax, the third most abundant shark below $1000 \mathrm{~m}$, seems to be more similar to that of Centroscymnus coelolepis than of Galeus melastomus. The diet of E. spinax has been carefully studied in Mediterranean waters, but only on the upper slope (Wurtz \& Vacchi 1978, MacPherson 1980). This species shows a preference for cephalopods, especially the adult specimens which inhabit the greater depths (Wurtz \& Vacchi 1978).

In this study it was not possible to obtain a sufficient number of samples of Etmopterus spinax because of its strong pelagic habits (Grey 1956, MacPherson 1980). However, personal observations verify the size increase with depth, and its specialization in the capture of cephalopods. Nineteen individuals which were collected between 984 and $1488 \mathrm{~m}$ were exclusively adults over $30 \mathrm{~cm}$ length. This bathymetric range coincides with the range of Galeus melastomus and does not overlap with the range of Centroscymnus coelolepis. Cephalopods were found in the stomachs of 4 individuals $(F=100 \%)$. This suggests a trophic strategy which is parallel to that of $C$. coelolepis.

These results suggest that competition is more likely between Centroscymnus coelolepis and Etmopterus spinax than between $C$. coelolepis and Galeus melastomus. This could explain the bathymetric movement of C. coelolepis in the western Mediterranean as a result of the vertical ranges along the depth gradient being more compressed by interspecific competition between members of higher trophic levels (Rex 1977).

Finally it is interesting to note the variations in the percentage of empty stomachs, the average of prey per stomach and the diversity of the diet. The percentage of empty stomachs increases with depth, reaching a very high value in the case of Centroscymnus coelolepis. In the same way, the average number of prey per stomach decreases with depth (from 5.5 in Galeus melastomus of the upper slope to 1.3 in C. coelolepis). The trophic diversity is also less in this species.

In our opinion, these factors are indicative of the increasing resource scarceness along the depth gradient in the western Mediterranean (Thiel 1983, Pérès 1985, personal observations on the decapod crustacean and fish biomass), which causes a change in the life strategy of both sharks. This tendency is also noticed in other aspects of their biology. Centroscymnus coelolepis shows a conservative life history, which is reflected in low fecundity and long periods of gestation of the embryos (Yano \& Tanaka 1988). This species seems to be better adapted to a poorer environment (lower slope) than to the upper and middle slope, which is occupied by Galeus melastomus, an oviparous species with a higher fecundity (Capapé \& Zaouali 1977).

Acknowledgements. For their help in identifying food items, we thank Dr M. Durfort (Departament Biologia Cel.lular, Universitat de Barcelona) and F. Giró (Departament Medi Ambient, Generalitat de Catalunya); Dr D. Lloris and P. Rubiés (Institut Ciències del Mar ICM-Barcelona) who identified mesopelagic fishes; F. Pagés (ICM), who identified Hydrozod; and R. Villanueva and Dr P. Sánchez (ICM), who identified cephalopods. We also thank Drs J. Retana (CREAF Facultat de Ciències, UAB), P. Abelló (ICM) and J. D. M. Gordon (Dunstaffnage Marine Laboratory, Oban) for their comments on the manuscript; Mrs. María Codorniu for the English translation, and J. M.Anguita for drawing the figures. Thanks are due to all the members of the research programs BATIMAR, ABISMAR and PONT'90 for their collaboration, specially to Drs J. Rucabado, D. Lloris, J Matallanas and F. Sardà. BATIMAR project was financed by CSIC and CAICYT (reference PAC 86-008/ID 821). ABISMAR and PONT'90 projects were financed by CSIC. This study was also supported by 'Fundació Caixa de Barcelona: Ajuts a la Recerca, 1989, Ambit Pesca'

\section{LITERATURE CITED}

Abelló, P., Valladares, F. J., Castellón, A. (1988). Analysis of the structure of decapod crustacean assemblages off the Catalan coast (North-West Mediterranean). Mar. Biol. 98: 39-49

Allué, C. (1985). Composición y estructura de la comunidad de peces demersales frente a Barcelona (Años 1980-1981). Thalassas 3(1): $57-90$

Allué, R., Allué, C., Rucabado, J., Lloris, D. (1985). Ichtyofaune des eaux profondes dans la Mer Catalane. Rapp. P.-v. Réun. Comm int. Explor. scient. Mer Méditerr. 29(8): $111-114$

Bauchot, M.-L. (1987a). Scyliorhinidae. In: Fischer, W., Bauchot, M.-L., Schneider, M. (eds.) Fiches FAO d'identification des espèces pour les besoins de la pêche (Révision 1). Méditerranée et Mer Noire. Zone de pêche 37 . Vol. 2. FAO, Rome

Bauchot, M.-L. (1987b). Squalidae. In: Fischer, W., Bauchot, M.-L., Schneider, M. (eds.) Fiches FAO d'identification des espèces pour les besoins de la pêche (Révision 1). Méditerranée et Mer Noire. Zone de pêche 37. Vol. 2. $\mathrm{FAO}$, Rome

Blaber, S. J., Bulman, C. M. (1987). Diets of fishes of the upper continental slope of eastern Tasmania: content, caloric values, dietary overlap and trophic relationships. Mar. Biol. 95: 345-357

Capapé, C., Zaouali, J. (1976). Contribution à la biologie des Scyliorhinidae des côtes tunisiennes. V. Galeus mela- 
stomus Rafinesque, 1810. Régime alimentaire. Archs Inst. Pasteur Tunis 53(3): 281-292

Capapé, C., Zaouali, J. (1977). Contribution à la biologie des Scyliorhinidae des côtes tunisiennes. VI. Galeus melastomus Rafinesque, 1810. Répartition géographique et bathymétrique, sexualité, reproduction, fécondité. Cah. Biol. Mar, 18: 449-463

Cartes, J. E. (1991). Análısis de las comunidades y estructura trófica de los crustáceos decápodos batiales del mar Catalán. Ph.D. thesis, Univ. Politécnica de Catalunya

Clarke, M. R., Merrett, N. R. (1972). The significance of squid, whale and other remains from the stomachs of bottom living deep-sea fish. J. mar. biol. Ass. U.K. 52: 599-603

Compagno, L. J. V. (1984). FAO species catalogue. Vol. 4. Sharks of the world. An annotated and illustrated catalogue of sharks species known to date. Part 1. Hexanchiformes to Lamniformes. FAO Fish. Synop. (125) Vol. 4, part 1

Della Croce, N., Drago, N., Flocchini, G. (1988). Ricerche biologiche e geofisiche. Campagna oceanografica N/R 'Minerva' (14-31.8.1987). Universita di Genova, Instituto di Scienze Ambientali Marine, Rapp. Tecnico 24

Foxton, P. (1972). Observations on the vertical distribution of the genus Acanthephyra (Crustacea: Decapoda) in the eastern North Atlantic, with particular reference to species of the 'purpurea' group. Proc. R. Soc. Edinb. 73(30): 301-313

Fredj, G., Maurin, C. (1987). Les poissons dans la banque des données MEDIFAUNE. Application à l'étude des caractéristiques de la faune ichtyologique méditerranéenne. Cybium 11(3): 21,9-299

Golani, D. (1986/87). On deep-water sharks caught off the Mediterranean coast of Israel. Israel. J. Zool. 34(1-2): 23-31

Goodyear, R. H., Zahuranec, B. J., Pugh, L. W., Gibbs, R. H. Jr (1972). Ecology and vertical distribution of Mediterranean midwater fishes. In: Mediterranean Biological Studies, Final Report, Part 3. Smithsonian Institution, Washington

Grey, M. (1956). The distribution of fishes found below a depth of $2000 \mathrm{~m}$. Fieldiana, Zool. 36(2): 75-183

Haedrich, R. L., Merrett, N. R. (1988). Summary atlas of deepliving demersal fishes in the North Atlantic Basin. J. nat. Hist. 22: $1325-1362$

Hureau, J.-C. (1970). Biologie comparée de quelques poissons antarctiques (Nototheniddae). Bull. Inst. océanogr. Monaco 68(1391): $1-250$

Lagardère, J.-P. (1977). Recherches sur la distribution verticale et sur l'alimentation des crustaces décapodes benthiques de la pente continentale du golfe de Gascogne. Analyse des groupements carcinologiques. Bull. Cent. Étud. Rech. scient., Biarritz 11(4): 367-440

MacPherson, E. (1979). Ecological overlap between Macrourids in the western Mediterranean Sea. Mar. Biol. 53: $149-159$

MacPherson, E. (1980). Regimen alimentaire de Galeus melastomus Rafinesque, 1810, Etmopterus spinax (L., 1758) et Scymnorhinus licha (Bonnaterre. 1788) en Méditerranée occidentale. Vie Milieu 30: 139-148

MacPherson. E. (1981). Resource partitioning in a Mediterranean demersal fish community. Mar. Ecol. Prog. Ser. 4: $183-193$

Marshall, N. B. (1979). Developments in deep-sea biology. Blandford Press Ltd, Poole, Dorset

Marshall, N. B., Merrett, N. R. (1977). The existence of a benthopelagic fauna on the deep-sea. Deep Sea Res. 24 (Suppl.): 483-497

Mattson, S. (1981). The food of Galeus melastomus, Gadiculus argenteus thori. Trisopterus esmarkii, Rhinonemus cumbrius and Glyptocephalus cynoglossus (Pisces) caught during the day with shrimp trawl in a west Norwegian fjord. Sarsia 66: 109-127

Mauchline, J., Gordon, J D. M. (1983). Diets of sharks and chimaeroids of the Rockall Trough, northeastern Atlantic Ocean. Mar. Biol. 75: 269-278

Mauchline, J., Gordon, J D. M. (1985). Trophic diversity in deep-sea fish. J. Fish Biol. 26: 527-535

Merrett, N. R., Marshall, N. B. (1981). Observations on the ecology of deep-sea bottom living fishes collected off northwest Africa $\left(08^{\circ}-27^{\circ} \mathrm{N}\right)$. Prog. Oceanog. 9: 185-244

Pérès, J. M. (1985). History of the Mediterranean biota and the colonization of the depths. In: Margalef, R. (ed.) western Mediterranean. Pergamon Press, New York

Pinkas, L., Oliphant, M. S., Iverson, I. L. K. (1971). Food habits of albacore, bluefin tuna and bonito in California waters. Calif. Fish Game Fish. Bull. 152: 1-105

Relini Orsi, L., Wurtz, M. (1977). Patterns and overlap in the feeding of two selachians of bathyal fishing grounds in the Ligurian sea. Rapp. P.-v. Réun.Commn int. Explor scient. Mer Méditerr. 24(5): 89-93

Rex, M. A. (1977). Zonation in deep-sea gastropods: the importance of biological interactions to rates of zonation. In: Keegan, B. F., Ceidigh, P. O., Boaden, P. J. S. (eds.) Biology of benthic organisms. Pergamon Press, New York

Roper, C. F. E. (1972). Ecology and vertical distribution of Mediterranean pelagic cephalopods. In: Mediterranean biological studies, Final Report, Part 5. Smithsonian Institution, Washington

Rosecchi, E., Nouaze, Y (1987). Comparaison de cinq indices alimentaires utilisés dans l'analyse des contenus stomacaux. Rev. Trav. Inst. Pêches, marit. 49(3-4): 111-123

Salat, J., Cruzado, A. (1981). Masses d'eau dans la Méditerranée occidentale: Mer Catalane et eaux adjacentes. Rapp. P.-v. Réun. Commn int. Explor. scient. Mer Méditerr. 27(6): 201-209

Schoener, T. W. (1974). Resource partitioning in ecological communities. Science 185: 27-39

Sedberry, G. R., Musick, J. A. (1978). Feeding strategies of some demersal fishes of the continental slope and rise of $f$ the mid-Atlantic coast of the USA. Mar. Biol. 44: 357-375

Shannon, C. E., Weaver, W. (1949). The mathematical theory of communication. University of lllinois Press, Urbana

Sokal, R. R., Rohlf, F. J. (1969). Biometry: the principles and practice of statistics in biological research. W. H. Freeman and Co., San Francisco

Springer, S. (1967). Social organization of sharks populations. In: Gilbert, R. F., Matheuson, R. F., Rall, D. P. (eds.) Sharks, skates and rays. John Hopkins Press, Standford

Thiel. H. (1983). Meiobenthos and nanobenthos of the deep sea. In: Rowe, G. T. (ed.) Deep-sea biology. The sea. Vol. 8. John Wiley \& Sons, New York

Torchio, M., Michelangeli, M. (1971). Prima segnalazione in acque italiane di uno squalidae del genero Centroscymnus. Natura, Milano 62/3: 241-245

Tortonese, E. (1956). Leptocardia, Ciclostomata, Selachii. In: Fauna d'Italia. 2. Calderıni, Bologna

Wurtz, M., Vacchi, M. (1978). Ricerca di cicli nittemerali nell'alimentazione di Selacl batiali. Quad. Lab. Tecnol. Pesca 3 (Suppl): 155-164

Yano, K., Tanaka, S. (1984). Some biological aspects of the deep sea squaloid shark Centroscymnus from Suruga Bay, Japan. Bull. Jpn Soc. Fish. 50(2): 249-256

Yano, K., Tanaka, S. (1988). Size at maturity. Reproductive cycle, fecundity, and depth segregation of the deep sea squaloid sharks Centroscymnus owstoni and $C$. coelolepis in Suruga Bay, Japan. Nippon Sulsan Gakkaishi 54(2): $167-174$ 